\title{
Biological sources of L-DOPA: An alternative approach
}

\author{
Sushama A. Patil ${ }^{1}$, Onkar A. Apine ${ }^{1}$, Shripad N. Surwase ${ }^{2}$, Jyoti P. Jadhav ${ }^{1 *}$ \\ ${ }^{1}$ Department of Biotechnology, Shivaji University, Kolhapur, India; ${ }^{2}$ Corresponding Author: jpjbiochem@gmail.com \\ ${ }^{2}$ Department of Microbiology, Shivaji University, Kolhapur, India
}

Received 30 November 2012; revised 30 December 2012; accepted 10 January 2013

Copyright (C) 2013 Sushama A. Patil et al. This is an open access article distributed under the Creative Commons Attribution License, which permits unrestricted use, distribution, and reproduction in any medium, provided the original work is properly cited.

\begin{abstract}
Parkinson's disease was first formally identified by British physician James Parkinson in 1817 as "The Shaking Palsy". L-DOPA (3,4-dihydroxyphenyl-L-alanine) has been considered as a gold-standard treatment for Parkinson's disease. The world market for L-DOPA is about $250 \mathrm{t} /$ year and the total market volume is about $\$ 101$ billion per year. The present review summarizes the different biological sources for the production of L-DOPA. The process for L-DOPA production from different biological sources has advantages over the chemical methods such as, enantiometrically pure L-DOPA, less incubation time and cost effective method. L-DOPA is found naturally in certain plant foods, particularly broad beans which found to replenish brain levels of L-DOPA even more quickly, and for longer periods, than conventional medication.
\end{abstract}

Keywords: Parkinson's Disease; L-DOPA; Biological Sources

\section{INTRODUCTION}

Parkinson's disease (PD) has been a constant challenge to public health around the world [1]. 3,4-dihydroxy phenyl-L-alanine (L-DOPA) is an amino acid analogue and drug of choice in the PD-a degenerative neurological disorder [2]. In the United States alone, about 1 million people are affected by PD and worldwide about 5 million. PD occurs among $1 \%$ of individuals aged 60 years while $4 \%$ of those 80 years old. The disease (PD) is characterized by progressive death of dopamine producing neurons in the basal ganglia of the brain [3-5]. Loss of the neurotransmitter dopamine can cause a number of effects, including rigidity (muscles resistant to movement), akinesia (inability to initiate movement), bradykinesia (slowness of movement), and rest tremor [4]. Many brain cells of PD patients contain Lewy bodies which are unusual deposits or clumps of the protein alpha-synuclein, along with other proteins. Researchers are unable to find out formation of Lewy bodies or their role in development of the disease. For many decades, there were no effective treatments for PD, and it was thought to be a terminal illness. But in the 1940s and 1950s, neurosurgeons began to perform surgery on the basal ganglia of brain which gave little cure in PD symptoms. Though surgery was effective, it was risky, with about 12 percent of patients dying as a result of operation. The biggest advancement in Parkinson's treatment came in the 1960 s, when researchers identified low levels of dopamine in brain among diseased persons. This research revolutionized the treatment of $\mathrm{PD}$, led to the development of levodopa, also called L-DOPA (Larodopa, Dopar), which is been used as medication [6]. L-DOPA can easily cross the blood-brain barrier and gets converted into dopamine, it can be administered orally to relieve the symptoms of PD [7]. Levodopa is still the cornerstone of Parkinson's treatment today.

Within the past three years, L-DOPA therapy has been considered as the subject of several extensive reviews by investigators in various parts of the world. The preliminary studies in both animals and humans date back to 1957 while first clinical trials to 1960 and 1961 [2]. This review summarizes the biological sources for L-DOPA production which can be used as an alternative for chemically synthesized drugs, surgery and multidisciplinary management against the disease.

\section{BIOCHEMISTRY OF DOPAMINE}

Interest in L-DOPA therapy for Parkinson's disease has been considerably enhanced since the recent release of this drug to all medical practitioners. Both experimental and clinical studies have suggested that the depletion of dopamine can be corrected by the administration 
of L-DOPA either orally or intravenously. A level of homovanillic acid (the main breakdown product of dopamine) in the cerebrospinal fluid of patients before and after the administration of oral L-DOPA proves its applicability [2].

Parkinson's disease affects a part of brain called the "basal ganglia", which controls movement. Cells in the basal ganglia begin to degenerate as a result of the condition, and lose of their ability to produce a neurotransmitter (a chemical that carries messages between brain and nerve cells) called dopamine. As dopamine levels drop, the production of another neurotransmitter, called acetylcholine, increases. The balance between these two is critical, because they have opposite effects; acetylcholine stimulating muscle contraction, and dopamine damping it down. When the balance shifts in favour of acetylcholine, muscles become rigid with increasing jerky movements which are difficult to control this is often accompanied by tremors in hands. Whilst conventional drugs can be administered to control symptoms, they have a range of unpleasant side effects and cannot limit its progression. During the early stages of the disease, conventional drugs, called anticholinergics, can reduce symptoms of muscle rigidity and excess salivation by blocking the action of acetylcholine. However, they can cause dry mouth, constipation, anxiety, drowsiness and blurred vision. Whereas, direct administration of L-DOPA also has dangerous side-effects, including nausea, internal bleeding, palpitations, dizziness and depression because of it is being converted to dopamine before it reaches to brain.

\section{L-DOPA TOXICITY}

A number of PD patients treated with L-DOPA. Patients have to suffer a variety of side effects; most commonly are nausea, vomiting, low blood pressure and restlessness. The drug can also cause drowsiness or sudden sleep onset, which can make driving and other activities dangerous. The repeated pulsatile stimulation of striatal dopamine receptors with chronic oral L-DOPA treatment induces plastic changes in basal ganglia circuits that can lead to the development of motor response complications (MRC). A more pressing concern regarding L-DOPA is it causes hallucinations and psychosis after long-term use. Some patients exhibit severe dyskinesias soon after starting low doses of L-DOPA. There are controversies in the treatment, whether it causes the motor complications or it is toxic to dopaminergic neurons, but it has not yet been proven and clinical trials have not clarified this situation.

There were number of therapies have been developed to improve PD management, such as dopaminergic agonists, inhibitors of catechol-O-methyltransferase (COMT) and monoamine oxidase (MAO-B). In combination therapy usually, patients are given levodopa combined with another substance called carbidopa (decarboxylase inhibitor). Addition of carbidopa lowers the amount of levodopa that is required and may reduce some of its side effects such as nausea and vomiting by reducing the supply of "free" dopamine outside the brain. Carbidopa delays the conversion of levodopa into dopamine until it reaches the brain, preventing or diminishing some of the side effects that often accompany levodopa therapy. It also reduces the amount of needed levodopa.

L-DOPA is very useful drug for reducing the tremors and other symptoms of PD during the early stages of the disease. It allows the majority of PD patients to extend their period of time of normal and productive lives. The dramatic improvement can be seen in PD patients after starting levodopa therapy. However, in order to get maximum benefit there is need to increase the dose gradually. A high-protein diet can interfere with the absorption of levodopa, so physicians recommend that patients shouldn't take protein-rich meals during their early stages of the treatment. L-DOPA therapy is necessary for PD patients as there is no other therapy provides more powerful antiparkinsonian effect.

\section{SYNTHESIS OF L-DOPA}

\subsection{Chemical Synthesis}

Chemical synthesis of L-DOPA involves use of extensive chemicals, catalyst under harsh production conditions [8-10]. Resultant L-DOPA by the process is racemic DL mixture, which is inactive and to separate enantiometrically pure L-DOPA is very difficult. The recemic mixture was easy to obtain but difficult to separate by the time it has been resolved, the projected costs doubled. Monsanto's position in vanillin, which provided the L-DOPA moiety, found that they were custom manufacturing a recemic intermediate, which was done by deblocking to L-DOPA according to Hoffman-LoRche. The synthesis, which followed closely the Erlenmeyer azlactone procedure described in organic synthesis, went by way of a pyrochiral enamide, which was hydrogenated to block DL-DOPA [11,12]. Currently in the market the available tablets for L-DOPA are under various brand names Sinemet ${ }^{\circledR}$, Atamet $^{(}$, Parcopa $\left.^{(}\right)$and Stalevo ${ }^{\circledR}$. More over L-DOPA obtained from mentioned chemical methods was found to be with $90 \%$ recovery.

\subsection{Biological Sources}

Until the middle of the 20th century, the amino acid 3,4-dihydroxyphenylalanine (L-DOPA) was just seen as an intermediate in the biological synthesis of melanin and epinephrine. In the earliest 1960s, it was proved that, L-DOPA is a neurotransmitter precursor has wide therapeutic applications [9]. There were many biological sources reported for enantiometrically pure L-DOPA (Table 1). 
Table 1. Different Biological sources for L-DOPA production.

\begin{tabular}{|c|c|c|}
\hline Biological sources & Yield of L-DOPA & References \\
\hline \multicolumn{3}{|l|}{ Enzymatic synthesis } \\
\hline E. intermedia cells (polyacrylamide gels) & $5.4 \mathrm{~g} \cdot \mathrm{l}^{-1}$ & {$[16]$} \\
\hline E. intermedia cells (carrageenan gel) & $7.8 \mathrm{~g} \cdot \mathrm{l}^{-1}$ & [17] \\
\hline Mushroom tyrosinase (Nylon 66) & $0.143 \mathrm{~g}$ & {$[18]$} \\
\hline $\begin{array}{c}\text { Chitosan flakes } \\
\text { Non optimized batch reaction } \\
\text { optimized batch reaction }\end{array}$ & $\begin{array}{l}44.86 \mathrm{mg} \cdot \mathrm{l}^{-1} \cdot \mathrm{h}^{-1} \\
54 \mathrm{mg} \cdot \mathrm{l}^{-1} \cdot \mathrm{h}^{-1}\end{array}$ & [19] \\
\hline Mushroom tyrosinase (zeolite) & $36 \mathrm{mg} \cdot \mathrm{l}^{-1} \cdot \mathrm{h}^{-1}$ & {$[20]$} \\
\hline $\begin{array}{l}\text { Modify poystryene } \\
\text { PSNH } \\
\text { PSCL }\end{array}$ & $\begin{array}{l}1.39 \mathrm{mg} \\
1.99 \mathrm{mg}\end{array}$ & {$[21]$} \\
\hline Cu-alginate & $4.5 \mathrm{mg} \cdot 1^{-1} \cdot \mathrm{h}^{-1}$ & [22] \\
\hline $\begin{array}{c}\text { Mushroom tyrosinase } \\
\text { On PEI } \\
\text { On activated on agar blocks } \\
\text { On activated agar particles }\end{array}$ & $\begin{array}{l}25 \mathrm{mg} \\
42 \mathrm{mg} \\
73 \mathrm{mg}\end{array}$ & {$[23]$} \\
\hline \multicolumn{3}{|l|}{ Fungi } \\
\hline Aspergillus oryzae IAM2625 & $0.88 \mathrm{~g}$ & {$[24]$} \\
\hline Stemonitis herbicola & $50 \mathrm{mg}$ & {$[25]$} \\
\hline Aspergillus oryzae ( mutant) & $1.28 \mathrm{mg} / \mathrm{ml}$ & {$[26]$} \\
\hline Aspergillus oryzae & $1.28 \mathrm{mg} / \mathrm{ml}$ & [27] \\
\hline Aspergillus oryzae UV7( double mutant) & $1.28 \mathrm{mg} \mathrm{ml}$ & {$[28]$} \\
\hline Aspergillus oryzae & $1.86 \mathrm{mg} / \mathrm{ml}$ & [29] \\
\hline Aspergillus oryzae UV-7 & $444 \mathrm{~g}$ cells & {$[30]$} \\
\hline Aspergillus oryzae ME2 (Illite) & $1.686 \mathrm{mg} / \mathrm{ml}$ & {$[31]$} \\
\hline Aspergillus oryzae ME2 (Celite) & $0.428 \mathrm{mg} / \mathrm{ml}$ & {$[32]$} \\
\hline Aspergillus oryzae (Double mutant) & $300 \mathrm{mg}$ & [33] \\
\hline Aspergillus oryzae IIB-6 & $1.34 \mathrm{mg} / \mathrm{ml}$ & {$[34]$} \\
\hline Acremonium retilum & $0.89 \mathrm{mg} / \mathrm{ml}$ & {$[35]$} \\
\hline Aspergillus niger & $0.365 \mathrm{mg} / \mathrm{ml}$ & {$[36]$} \\
\hline Actinomycetes & $28.6 \%$ & [37] \\
\hline \multicolumn{3}{|l|}{ Yeast } \\
\hline Yarrowia lipolytica NRRL-143 & $2.96 \mathrm{mg} / \mathrm{ml}$ & [38] \\
\hline Egyptian halophilic black yeast & $66 \mathrm{ug} / \mathrm{ml}$ & [39] \\
\hline \multicolumn{3}{|l|}{ Bacteria } \\
\hline Vibrio tyrosinaticus & $4 \mathrm{mg} / \mathrm{ml}$ & {$[40]$} \\
\hline Pseudomonas melanogenum & $8 \mathrm{mg} / \mathrm{ml}$ & [41] \\
\hline E. coli W(ATCC 11105) (p-hydroxyphenyl acetate 3-hydroxylase) & $48 \mathrm{mM}$ in reaction mixture & [42] \\
\hline Bacillus sp. JPJ & $0.497 \mathrm{mg} / \mathrm{ml}$ & [7] \\
\hline Recombinant Erwinia herbicola cells strain AJ2985 & $15 \mathrm{~g} / \mathrm{l} / \mathrm{h}$ & {$[45]$} \\
\hline
\end{tabular}




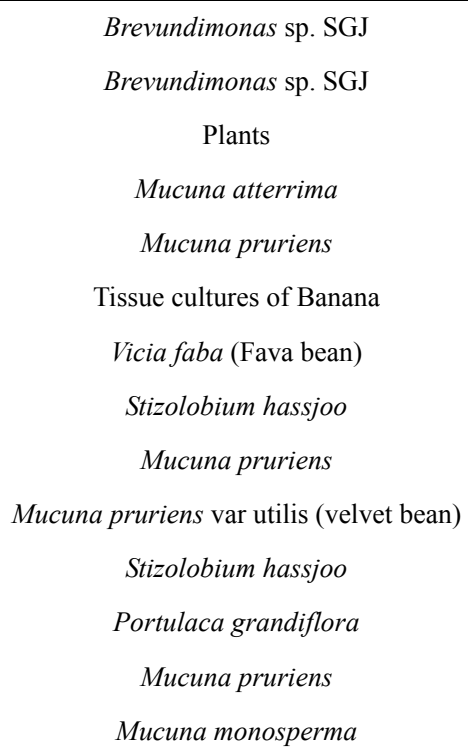

$\begin{array}{cc}3.81 \mathrm{mg} / \mathrm{ml} & {[43]} \\ 3.361 \mathrm{mg} / \mathrm{ml} & {[44]} \\ & \\ 4.5 \% & {[46]} \\ - & {[47]} \\ - & {[53]} \\ 3.4 \mathrm{mg} / \mathrm{g} \mathrm{DW} & {[52]} \\ 2 \mathrm{~g} / \mathrm{l} & {[54]} \\ 3.54 \% \mathrm{DW} & {[48]} \\ 6.36 \% \mathrm{~W} / \mathrm{W} & {[49]} \\ 495 \mathrm{mg} / \mathrm{ml} & {[55]} \\ 48.8 \mathrm{mg} / \mathrm{l} / \mathrm{h} & {[56]} \\ 24 \mathrm{~g} / \mathrm{DW} & {[50]} \\ 5.48 \% \mathrm{DW} & {[51]}\end{array}$

The production of L-DOPA from biological sources involves the oxidation of L-tyrosine by enzyme tyrosinase (E.C.1.14.18.1), which is copper containing enzyme widely distributed in plants, animals and microorganisms [13]. Oxidation product of tyrosinase subsequently converted in to melanin; as it functions like alternative substrate for tyrosinase ultimately stimulate catalytic efficiency. This cresolase and catecholase mechanisms occurs in melanin synthesis pathway in microorganisms, while in brain naturally the L-tyrosine is converted in the epinephrine finally by the series of enzymatic reactions initiated with tyrosine hydroxylase [14]. The process for the synthesis of L-DOPA form different species is carried out using various methods.

\subsubsection{Enzymatic Synthesis}

Mushroom tyrosinase has been commercially used in the enzymatic synthesis of L-DOPA by enzyme immobilization [15]. It lowers the production cost due to the reusability of the enzymes. The various techniques used for enzyme immobilization include entrapment in polymeric gels, adsorption onto insoluble materials, encapsulation in membranes, cross-linking with bifunctional or multifunctional reagents and linking to an insoluble carrier [16-23]. The substrate used for the synthesis of LDOPA were catechol, sodium pyruvate and ammonium acetate.

\subsubsection{Fungal Sources}

Mostly, L-DOPA from fungal species was obtained in the reaction mixture containing substrate L-tyrosine and mycelia in the buffer. Briefly, the mycelia were suspended in reaction mixture containing L-tyrosine, Lascorbic acid and intact mycelia under optimized condi- tion. In addition, specific additives were used as elicitors for enhanced yield of L-DOPA. L-DOPA produced by the method was enantiometrically pure as well as it is cost effective. Similarly, biotransformation of L-DOPA from L-tyrosine was carried out using Acremonium reticulum by submerged fermentation process yields more amount of L-DOPA in the broth [24-37]. Production of L-DOPA also reported from yeast species $[38,39]$.

\subsubsection{Bacterial Sources}

L-DOPA produced from different bacterial species includes both in broth as well as in buffer with substrate and acclimatized cells. Initially, the medium optimization was performed in order to maximum production of L-DOPA. To overcome the tedious downstream processing after production of L-DOPA by this process, use of acclimatized cells with buffer gave the best results within less time and experimentation [7,40-44]. In case of L-DOPA production using enzymatic process of recombinant $E$. herbicola cells carrying a mutant transcripttional regulator TyrR yield obtained was near about 15 $\mathrm{g} \cdot \mathrm{l}^{-1} \cdot \mathrm{h}^{-1}[45]$. This mechanism of synthesis is now accepted commercially by the industry named as Aginomoto CO.LTD.

\subsubsection{Plants}

Plants were exploited as an alternate source for the isolation of L-DOPA and in a screening survey; more than 1000 species in 135 plant families have been screened. Genus Mucuna (Leguminosae) was found to contain the maximum level of L-DOPA which has been successfully exploited commercially [46-51]. Among the various species of Mucuna, M. holtonii, M. pruriens and M. monosperma were having promising L-DOPA content 
in their seeds. Fava bean (Vicia faba), seed sprouts, pods, and broad beans are one of nature's best plant sources of L-DOPA widely cultivated legume, commonly consumed and have anti-Parkinson's effect [52]. Shoot and callus cultures of banana showed accumulation of L-DOPA when the culture supplemented with tyrosine and phenylalanine. Bananas are grown in many developing countries all over the world and the fruit is known to have soothing effect in the nervous system [53]. There are many plant sources reported for L-DOPA production [54-56].

\section{CONCLUSION}

Most of the L-DOPA isolated is either from natural sources or synthesized chemically, but biological sources could be used as an alternative source for L-DOPA production. The alternative sources of L-DOPA and a further clinical trial will open the subject of extensive research. Chemical synthesis methods were time consuming, required costly and toxic chemicals like catechol, pyrocatechol and also resulted in recemic mixture of L-DOPA. Biological synthesis of L-DOPA will be the most promising approach to overcome ill-effects of chemical drugs. Different sources like enzymatic, fungal, bacterial and plant, yield maximum amount of enantiometrically pure L-DOPA under optimized cultural conditions. Most of the plant sources belong to legumes which can be used for the consumption, along with their L-DOPA content; role of plant phenolics (antioxidants, antimutagens and scavengers of free radicals) becomes vital as far as total health is concerned. L-DOPA from natural sources reduces the secondary complications also helps to delay the progression of the disease. Taken together, most of the research on synthesis of L-DOPA has been done using biological sources but now it is necessary to find exact mechanism of action and chances to cure the Parkinson's disease in future.

\section{ACKNOWLEDGEMENTS}

Junior research fellowship to Ms. Sushama Patil and Mr. Onkar Apine from the UGC-BSR, New Delhi, India is gratefully acknowledged. Corresponding author wish to thank DBT-IPLS programme.

\section{REFERENCES}

[1] National Human Genome Research Institute (1998) Parkinson's disease-Research news.

[2] Kofman, O. (1971) Treatment of Parkinson's disease with L-DOPA: A current appraisal. The Canadian Medical Association Journal Le Journal de l'Association Medicale Canadienne, 104, 483-487.

[3] Bhatnagar, S. and Andy, O. (1995) Neuroscience for the study of communicative disorders. Williams and Wilkins,
Baltimore.

[4] Brodal, P. (1998) The central nervous system: Structure and function. 2nd Edition, Oxford University Press, New York.

[5] Lang, A. and Lozano, A. (1998) Parkinson's disease: First of two parts. The New England Journal of Medicine, 339, 1044-1053. doi:10.1056/NEJM199810083391506

[6] Davie, C. (2008) A review of Parkinson's disease. British Medical Bulletin, 86, 109-127. doi:10.1093/bmb/ldn013

[7] Surwase, S.N. and Jadhav J.P. (2010) Bioconversion of L-tyrosine to L-DOPA by a novel bacterium Bacillus sp. JPJ. Amino Acids, 41, 495-506. doi:10.1007/s00726-010-0768-Z

[8] Knowles, W. (2003) Asymmetric hydrogenations. Advanced Synthesis and Catalysis, 345, 3-13. doi:10.1002/adsc.200390028

[9] Valdes, R., Puzer, L., Gomes, M., Marques, C., Aranda, D., Bastos, M., Gemal, A., Antunes, O., et al. (2004) Production of L-DOPA under heterogeneous asymmetric catalysis. Catalysis Communications, 5, 631-634. doi:10.1016/j.catcom.2004.07.018

[10] Lee, S.G., Rao, H.S., Hong, S.P., Kim, E.H., Sung, M.H., et al. (1996) Production of L-dopa by thermostable tyrosine phenol-lyase of a thermophilic Symbiobacterium spp. over expressed in recombinant Escherichia coli. Journal of Microbiology and Biotechnology, 6, 98-102.

[11] Knowles, W.S. (2001) Nobel lecture asymmetric hydrogenations. Monsanto Co., St. Louis.

[12] Blaser, H.U., Spindler, F. and Studer, M. (2001) Enantioselective catalysis in fine chemicals production. Applied Catalysis A: General, 221, 119-143. doi:10.1016/S0926-860X(01)00801-8

[13] Claus, H. and Decker, H. (2006) Bacterial tyrosinases. Systematic and Applied Microbiology, 29, 3-14. doi:10.1016/j.syapm.2005.07.012

[14] Graeme, E., Hua, T., Courtney, H., Jun, M., Suzanne, R., Vincent, J. et al. (2003) Tyrosinase: A developmentally specific major determinant of peripheral dopamine. The Federation of American Societies for Experimental Biology, 17, 1248-1255. doi:10.1096/fj.02-0736com

[15] Seo, S.Y., Sharma, V.K., Sharma, N., et al. (2003) Mushroom tyrosinase: Recent prospects. Journal of Agricultural and Food Chemistry, 51, 2837-2853. doi:10.1021/jf020826f

[16] Para, G. and Baratti, G. (1988) Synthesis of L-dopa by Escherichia inwrmedia cells immobilized in a polyacrylamide gel. Applied Microbiology Biotechnology, 28, 222-228. doi:10.1007/BF00250445

[17] Para, G. and Baratti, G. (1988) Synthesis of L-Dopa by Escherichia intermedia cells immobilized in a carrageenan gel. Enzyme and Microbial Technology, 10, 729735. doi:10.1016/0141-0229(88)90117-2

[18] Pialis, P., Maria, C., Hamann, J., Saville, B.A., et al. (1996) L-DOPA production from tyrosinase immobilized on nylon 6,6. Biotechnology and Bioengineering, 51, 141-147.

doi:10.1002/(SICI)1097-0290(19960720)51:2<141::AID- 


\section{BIT2>3.0.CO;2-J}

[19] Gabriela, M.J., Tito, M.A. and Denise, M.G. (2000) L-DOPA production by immobilized tyrosinase. Applied Biochemistry and Biotechnology, 84, 791-800.

[20] Seetharam, G. and Saville, B.A. (2002) L-DOPA production from tyrosinase immobilized on zeolite. Enzyme and Microbial Technology, 31, 747-753. doi:10.1016/S0141-0229(02)00182-5

[21] Ho, P.Y., Chiou, M.S. and Chao, A.C. (2003) Production of L-DOPA by tyrosinase immobilized on modified polystyrene. Applied Biochemistry and Biotechnology, 111, 139-152. doi:10.1385/ABAB:111:3:139

[22] Selma, A., Esra, C., Emine, B., Ulku, M., et al. (2007) Production of L-DOPA using Cu-alginate gel immobilized tyrosinase in a batch and packed bed reactor. Enzyme and Microbial Technology, 40, 683-687. doi:10.1016/i.enzmictec.2006.05.031

[23] Norouzian, D., Akbarzadeh, A., Mirdamadi, S., Khetami, S., Farhanghi, A., et al. (2007) Immobilization of mushroom tyrosinase by different methods in order to transform L-tyrosine to L-3,4-dihydroxyphenylalanine (Ldopa). Biotechnology, 6, 436-439. doi:10.3923/biotech.2007.436.439

[24] Haneda, K., Watanabe, S. and Takeda, I. (1971) Synthesis of 3,4-dihydroxyphenyl L-alanine from L-tyrosine by microorganisms. Applied Microbiology, 22, 721-722.

[25] Loganathan, P. (1998) Production of DL-DOPA from acellular slime-mould Stemonitis herbatica. Bioprocess Engineering, 18, 307-308.

[26] Ali, S., Haq, I. and Qadeer, M.A. (2002) Novel technique for microbial production of 3,4-dihydroxyphenyl Lalanine by a mutant strain of Aspergillus oryzae. Electronic Journal of Biotechnology, 5, 118-124. doi:10.2225/vol5-issue2-fulltext-2

[27] Haq, I. Ali, S. and Qadeer, M.A. (2002) Biosynthesis of L-DOPA by Aspergillus oryzae. Bioresource Technology, 85, 25-29. doi:10.1016/S0960-8524(02)00060-3

[28] Haq, I. and Ali, S. (2002) Microbiological transformation of L-tyrosine to 3,4-dihydroxyphenyl L-alanine (L-Dopa) by a mutant strain of Aspergillus oryzae UV-7. Current Microbiology, 45, 88-93. doi:10.1007/s00284-001-0080-y

[29] Haq, I., Ali, S., Qadeer, M.A., Iqbal, J., et al. (2003) Inducive effect of cresoquinone on microbiological transformation of L-tyrosine to 3,4-dihydroxyphenyl L-alanine by Aspergillus oryzae NG-11P1. Applied Microbiology Biotechnology, 60, 696-699.

[30] Ali, S., Haq, I., Qadeer, M.A., Rajoka M.I., et al. (2005) Double mutant of Aspergillus oryzae for improved production of L-dopa (3,4-dihydroxyphenyl-L-alanine) from L-tyrosine. Biotechnology and Applied Biochemistry, 42, 143-149. doi:10.1042/BA20040180

[31] Ali, S. and Haq, I. (2005) Innovative effect of illite on improved microbiological conversion of L-tyrosine to 3,4-dihydroxyphenyl L-alanine (L-DOPA) by Aspergillus oryzae ME2 under acidic reaction conditions. Current Microbiology, 53, 351-357.

[32] Ali, S. and Haq, I. (2006) Kinetic basis of celite (CM 2:1) addition on the biosynthesis of 3,4-dihydroxyphenyl-
L-alanine (L-DOPA) by Aspergillus oryzae ME2 using L-tyrosine as a basal substrate. World Journal of Microbiology \& Biotechnology, 22, 347-353. doi:10.1007/s11274-005-9040-1

[33] Haq, I. and Ali, S. (2006) Mutation of Aspergillus oryzae for improved production of 3,4-dihydroxyphenyl Lalanine (L-DOPA) from L-tyrosine. Brazilian Journal of Microbiology, 37, 78-86. doi:10.1590/S1517-83822006000100015

[34] Ali, S. and Haq, I. (2007) Technique for improved production of 3,4-dihydroxyphenyl L-alanine by Aspergillus oryzae. Pakistan Journal of Botany, 39, 623-627.

[35] Krishnaveni, R., Rathod, V., Thakur M.S., Neelgund, Y. F., et al. (2009) Transformation of L-Tyrosine to L-Dopa by a novel fungus, Acremonium rutilum, under submerged fermentation. Current Microbiology, 58, 122-128. doi:10.1007/s00284-008-9287-5

[36] Ali, S. and Haq, I. (2010) Production of 3,4-dihydroxy L-phenylalanine by a newly isolated Aspergillus niger and parameter significance analysis by Plackett-Burman design. BMC Biotechnology, 10, 86. doi:10.1186/1472-6750-10-86

[37] Sukumaram, C.P., Singh, D.V., Khedkar, P.D., Mahadevan, P. R. (1979) An actinomycete producing L-3,4dihydroxyphenylalanine from L-tyrosine. Journal of Bioscience, 1, 236-239. doi:10.1007/BF02706335

[38] Ali, S., Shultz, J.L. and Qadeer, M.A. (2007) High performance microbiological transformation of L-tyrosine to L-dopa by Yarrowia lipolytica NRRL-143. BMC Biotechnology, 7, 50. doi:10.1186/1472-6750-7-50

[39] Doaa, A.R., Magda, A. and Bendary, E.L. (2010) Production of 3,4-dihydroxyphenyl-L-alanine (L-DOPA) by Egyptian halophilic black yeast. World Journal of Microbiology Biotechnology, 27, 39-46.

[40] Yoshida, H., Tanaka, Y. and Nakayama, K. (1973) Production of 3,4-dihydroxyphenyl-L-alanine (L-DOPA) and its derivatives by Vibrio tyrosinaticus. Agricultural and Biological Chemistry, 37, 2121-2126. doi:10.1271/bbb1961.37.2121

[41] Yoshida, H., Tanaka, Y. and Nakayama, K. (1974) Production of 3,4-dihydroxyphenyl-L-alanine (L-DOPA) by Pseudomonas melanogenum. Agricultural and Biological Chemistry, 37, 2121-2126. doi:10.1271/bbb1961.37.2121

[42] Lee, J.Y. and Xun, L. (1998) Novel biological process for L-DOPA production from L-tyrosine by p-hydroxyphenylacetate 3-hydroxylase. Biotechnology Letters, 20, 479-482. doi:10.1023/A:1005440229420

[43] Surwase, S.N., Patil, S.A., Apine, O.A., Jadhav, J.P., et al. (2012) Efficient microbial conversion of L-tyrosine to L-DOPA by Brevundimonas sp. SGJ. Applied Biochemistry and Biotechnology, 5, 1015-1028. doi:10.1007/s12010-012-9564-4

[44] Surwase, S.N., Patil, S.A., Jadhav, S.B., Jadhav, J.P., et al. (2012) Optimization of L-DOPA production by Brevundimonas sp. SGJ using response surface methodology. Microbial Biotechnology, 5, 731-737. doi:10.1111/j.1751-7915.2012.00363.x

[45] Takashi, K., Takane, K., Hideyuki, S., Hidetsugu, N., 
Kenzo, Y., Hidehiko, K., et al. (2005) Effective production of 3,4-dihydroxyphenyl-L-alanine (L-DOPA) with Erwinia herbicola cells carrying a mutant transcriptional regulator TyrR. Journal of Biotechnology, 115, 303-306. doi:10.1016/i.jbiotec.2004.08.016

[46] Pieris, N., Jansz, E.R. and Dharmadara, H.M. (1980) Studies on Mucuna species of shri lanka the L-DOPA content of seeds. Journal of the National Science Council of Sri Lanka, 8, 35-40.

[47] Chattopadhyay, S., Datta, S.K. and Mahato, S.B. (1994) Production of L-DOPA from cell suspension culture of Mucuna pruriens. Plant Cell Reports, 13, 519-522. doi:10.1007/BF00232948

[48] Teixeira, A.A., Rich, E.C. and Szabo, N.J. (2003) Water extraction of L-DOPA from Mucuna bean. Tropical and Subtropical Agroecosystems, 1, 159-171.

[49] Egounlety, M. (2003) Processing of velvet bean (Mucuna pruriens var utilis) by fermentation. Tropical and Subtropical Agroecosystems, 1, 173-181.

[50] Chikagwa-Malunga, S.K., Adesogan, A.T., Salawu, M.B., Szabo, N.J., Littell, R.C., Kim S.C., Phatak, S.C., et al. (2009) Nutritional characterization of Mucuna pruiriens In vitro ruminal fluid fermentability of Mucuna pruriens, Mucuna L-DOPA and soybean meal incubated with or without L-DOPA. Animal Feed Science and Technology, 148, 51-67. doi:10.1016/j.anifeedsci.2008.03.005
[51] Inamdar, S., Joshi, S., Jadhav, J., Bapat, V. (2012) Innovative use of intact seeds of Mucuna monosperma wight for improved yield of L-DOPA. Natural Products and Bioprospect, 2, 16-20. doi:10.1007/s13659-011-0051-3

[52] Shetty, P., Attallah, M.T., Shetty, K. (2001) Enhancement of total phenolic, L-DOPA and proline content in germinating fava bean (Vicia faba) in response to bacterial elicitors. Food Biotechnology, 15, 47-67. doi:10.1081/FBT-100103894

[53] Bapat, V.A., Suprasanna, P., Ganapati, T.R., Rao, P.S., et al. (2000) In vitro production of L-dopa in tissue cultures of banana. Pharmaceutical Biology, 38, 271-273.

[54] Huang, S.Y. and Hu, J.J. (2001) Effects of gas composition on the cell growth and L-DOPA production in the suspension culture of Stizolobium hassjao. Journal of the Chinese Institute of Chemical Engineers, 32, 1-11.

[55] Sung, L.S. and Huang, S.Y. (2006) Lateral root bridging as a strategy to enhance L-DOPA production in Stizolobium hassjoo hairy root cultures by using a mesh hindrance mist trickling bioreactor. Biotechnology and Bioengineering, 94, 441-447. doi:10.1002/bit.20804

[56] Rani, N., Joy, B. and Abraham, E. (2007) Cell suspension cultures of Portulaca grandiflora as potent catalysts for biotransformation of L-tyrosine into L-DOPA, an antiParkinson's drug. Pharmaceutical Biology, 45, 48-53. doi:10.1080/13880200601026341 